\title{
Forage growth, biomass yield and nutrient content of two different hybrid Napier cultivars grown in Bangladesh
}

\author{
S Ahmed ${ }^{1 *}$, MRH Rakib ${ }^{1,2}$ and MA Jalil ${ }^{3}$
}

${ }^{1}$ Goat and Sheep Production Research Division, Bangladesh Livestock Research Institute, Savar, Dhaka-1341, Bangladesh; 'Department of Clinical Veterinary Medicine, College of Veterinary Medicine, China Agricultural University, Beijing, China; ${ }^{3}$ Animal Production Research Division, Bangladesh Livestock Research Institute, Savar, Dhaka-1341, Bangladesh

\begin{abstract}
A $2 \times 3$ factorial experiment was conducted to compare two cultivars; Bangladesh Livestock Research Institute developed Napier hybrid-3 (BN-3) (Pennisetum purpureum) and Pakchong-1 (Pennisetum purpureum $\times P$. glaucum) in terms of forage growth, biomass yield, and nutritional quality. Cultivars were cultivated in 03 blocks with 03 replicates and were harvested at 03 cutting periods (40, 50, and 60 days). Plot sizes for each cultivar were $25 \mathrm{~m}^{2}(5 \mathrm{~m} \times 5 \mathrm{~m})$, and in every plot, twenty-five stem cuttings with two healthy nodes per cutting were planted with $(1 \times 1) \mathrm{m}$ spacing. The effects of cultivar and cutting period were significant on plant height, leaves per tiller, leaf DM production, and leaf stem ratio (LSR). Highest plant height $(P<0.01)$ and leaves per tiller $(P<0.05)$ were consistently produced by $B N-3$, while Pakchong-1 produced the highest amount of CP $(P<0.05)$, LSR $(P<0.05)$, tiller diameter $(P<0.01)$ and diameter of the lowest node $(P<0.01)$. Based on the \%DM, DM yield, and CP yield, BN-3 performed better cutting at 50 days after the first plantation, but Pakchong-1 performed better cutting at 60 days after the first plantation. From the forage standpoint, Pakchong-1 seems to have little advantages over $\mathrm{BN}-3$ because of its higher DM, LSR, and CP production.
\end{abstract}

Keywords: cultivar, harvesting period, leaf stem ratio, quality, yield

Bangladesh Animal Husbandry Association. All rights reserved.

Bang. J. Anim. Sci. 2021. 50 (1):43-49

\section{Introduction}

Livestock is one of the essential component and fast-growing sector in Bangladesh's integrated and subsistence farming system. However, feeds and fodder scarcity is major limiting factor of livestock production in Bangladesh, resulting in low productivity, poor growth, and animal reproduction. A suitable animal feeding program ensures animal health, welfare, productivity, product safety, quality, and land use. Access to a permanent forage base is a physiological priority for ruminants and an economic priority for farmers (Dunièreet al., 2013). Different available grasses, e.g.,Pangola (Digitariaeriantha), Napier (Pennisetum purpureum), Ruzi (Brachiaria ruziziensis), German (Echinochloa polystachya), Splendida (Setaria splendida), and Para (Brachiariamutica) are commonly used in our country for small ruminants. However, the hybrid Napier cultivar; Pakchong-1 (Pennisetum purpureum $\times P$. glaucum) is recently introduced from Thailand, which is reported to grow over 3 $\mathrm{m}$ tall in less than two months, gives high yields, and can be harvested after 45 days with a CP concentration of 16-18\% (Kiyothong, 2014).
Nevertheless, forage crop performances are positively correlated with the area, location, and season (Tessema et al., 2010; Pandey and Roy, 2011). Thus, there is a need to verify whether Pakchong-1 can compete against the existing cultivars for forage yield, quality, and growth characteristics under Bangladesh conditions. Therefore, the present study was carried out to evaluate the harvest period's effect on forage growth, biomass yield, and nutritional quality responses of Pakchong-1 compared to $\mathrm{BN}-3$.

\section{Materials and Methods}

\section{Site of the experiment}

The experiment was conducted at Bangladesh Livestock Research Institute (BLRI), Savar, about 24 kilometers northwest of the capital city of Bangladesh. The site is located at $23^{\circ} 42^{\prime} 0^{\prime \prime}$ $\mathrm{N}, 90^{\circ} 22^{\prime} 30^{\prime \prime} \mathrm{E}$, at an altitude of $4 \mathrm{~mm}$ above the sea level (Huque, 2017). This area's meteorological conditions are more or less similar to the central part of the country concerning temperature, rainfall, and humidity. The study area is situated in a humid subtropical climate with large variations between summer and winter 
temperatures and significantly influenced by monsoons from May to September. The mean relative humidity ranged from $54 \%$ to $83 \%$. The annual average maximum temperature is about $36^{\circ} \mathrm{C}$, and the minimum temperature is about $12.7^{\circ} \mathrm{C}$, and the average annual rainfall is about 1,329 mm (LGED, 2014).

\section{Soil conditions}

The condition of the soil of the experimental site is clayed textured, which is strongly acidic $(\mathrm{pH}$ 4.5-5.7) containing a very little $(<1.5 \%)$ organic matter, and it belongs to the Madhupur Terrace Agro-ecological Zone of Bangladesh (Hasan et al., 2019; Huque, 2017).

\section{Description of cultivars}

BN-3 and Pakchong-1 grass were used in this study, where BLRI developed BN-3 grass through Napier hybrid accession selection. It is characterized by moderate height with profuse tillering. It has very few barbs in leaves and stems with better LSR. Although the flowering stage of this grass comes into a delay but can be first harvested 50-60 days after plantation with 40-45 days subsequent harvests (Sarker et al., 2019).On the other hand, Pakchong-1 was developed by the Department of Livestock Development, Thailand, which is reported to grow over $3 \mathrm{~m}$ tall in less than two months, gives high yields, and can be harvested after 45 days with a CP concentration of 16-18\% (Kiyothong, 2014).

\section{Land preparation and management}

The plot size for each cultivar was $25 \mathrm{~m}^{2}$ (5m $\times$ $5 \mathrm{~m})$. Twenty-five stem cuttings with two healthy nodes per cutting were planted in every plot on 28 July 2016 with $(1 \times 1) \mathrm{m}$ spacing. Before that, the land was prepared by proper ploughing and disc harrowing. Plants along the borders of each plot were excluded from the measurements. At each harvest period, only 05 plants per plot were sampled for studying plant morphology. After each cut, urea fertilizer was applied uniformly at the rate of $50 \mathrm{~kg} /$ hector. Weeds were slashed regularly at the time of cutting.

\section{Harvesting procedure and sample collection}

Both cultivars were harvested by cutting the stubble $05 \mathrm{~cm}$ above the ground level using hand sickles, and fresh stems and leaves of each of the 05 harvested plants were separated and weighed. At harvesting time, each plant constituted a bunch of tillers. Plant height, plant weight, basal circumference at $10 \mathrm{~cm}$ above ground level, number of tillers per plant, tiller diameter, leaves per tiller, leaves per plant, and the lowest node diameter were recorded. The plant height was measured from the base of the tiller to the topmost ligule. The diameter of the lowest node was measured with digital Vernier calipers. The total number of leaves was estimated from the tiller number per plant and leaf number per tiller.

For DM analysis, about $300 \mathrm{~g}$ of stems and leaves sub-samples were bulked separately. The subsamples' dry matter content was determined in an oven at $70^{\circ} \mathrm{C}$, for $48 \mathrm{~h}$. The dried samples were ground through a $1.0 \mathrm{~mm}$ screen for the determination of crude protein (Kjeldahl$\mathrm{N} \times 6.25$ ), acid detergent fibre (ADF), and neutral detergent fibre (NDF) contents (Van Soest et al., 1991).Based on DM \% and fresh stem and leaf yields. We estimated each plant's stem and leaf DM yield. Dry leaf weight was divided by dry stem weight to estimate the LSR.

\section{Experimental design and Data analysis}

A $2 \times 3$ factorial experiment ( 2 cultivars- $\mathrm{BN}-3$ and Pakchong-1 grass $\times 3$ cutting period at 40,50 , and 60 days) in a randomized block design was laid out in 3 blocks (3 replications). Considering the three cutting periods as treatment, their responses to cultivars biomass production performances and nutrient yield and contents (DM, CP, ADF, and NDF) were analysed in an ANOVA of a Randomized Block Design (RBD) using a general linear model of SPSS-20.0 statistical software program. Duncan's Multiple Range Test (DMRT) test was used to test the differences between means. Differences between means were considered significant if $P$ values were less than 0.05 .

\section{Results}

\section{Growth characteristics}

The effects of cultivar and cutting period on plant height, basal circumference, tiller number and diameter, leaves per tiller, and diameter of the lowest node are presented in Table 1. For cultivars, plant height followed the order BLRI Napier hybrid-3>Pakchong-1, $(P<0.01)$. In contrast, basal circumference and number of tillers for both cultivars were similar, but tiller diameter and diameter of the lowest node were significantly $(P<0.01)$ higher in Pakchong-1 than BLRI Napier hybrid-3. Cultivar also significantly affected the number of leaves per tiller (BLRI Napier hybrid-3>Pakchong-1, P<0.05). Similarly, the cutting period had significant effects on plant height and leaves per tiller, with height increased progressively as the cutting period increased $(P<0.01)$, while basal circumference, number of tiller, tiller diameter, and diameter of lowest node had no significant effect. 
Yield and nutrient content of Pakchong-1

Table 1: Effects of cultivar and cutting period on growth parameters of BLRI Napier hybrid-3 and Pakchong-1 cultivars (mean $\pm \mathrm{SE})$

\begin{tabular}{|c|c|c|c|c|c|c|c|}
\hline \multicolumn{2}{|c|}{ Treatments } & \multicolumn{6}{|c|}{ Parameters } \\
\hline & & $\begin{array}{l}\text { Plant } \\
\text { height } \\
(\mathrm{cm})\end{array}$ & $\begin{array}{l}\text { Basal } \\
\text { circumfere } \\
\text { nce }(\mathrm{cm})\end{array}$ & $\begin{array}{l}\text { No. of } \\
\text { tillers } \\
\text { (no.) }\end{array}$ & $\begin{array}{l}\text { Tiller } \\
\text { diameter } \\
(\mathbf{m m})\end{array}$ & $\begin{array}{l}\text { Leaves per } \\
\text { tiller (no.) }\end{array}$ & $\begin{array}{l}\text { Diamete } \\
\text { r of } \\
\text { lowest } \\
\text { node } \\
(\mathbf{m m})\end{array}$ \\
\hline \multirow{3}{*}{$\mathrm{BN}-3$} & $\begin{array}{c}40 \\
\text { days }\end{array}$ & $\begin{array}{c}182.06 \pm \\
10.05\end{array}$ & $81.4 \pm 8.72$ & $20.6 \pm 2.75$ & $12.92 \pm 0.72$ & $9.94 \pm 0.25$ & $\begin{array}{c}17.83 \pm \\
1.15\end{array}$ \\
\hline & $\begin{array}{c}50 \\
\text { days }\end{array}$ & $\begin{array}{c}221.8 \pm \\
7.9\end{array}$ & $74.2 \pm 3.22$ & $22.4 \pm 2.42$ & $12.48 \pm 0.16$ & $11.79 \pm 0.27$ & $\begin{array}{c}17.83 \pm \\
1.15\end{array}$ \\
\hline & $\begin{array}{l}60 \\
\text { days }\end{array}$ & $\begin{array}{c}308.4 \pm \\
6.33\end{array}$ & $74.2 \pm 5.8$ & $14.2 \pm 1.77$ & $13.62 \pm 0.75$ & $16.94 \pm 0.76$ & $\begin{array}{c}17.83 \pm \\
1.15\end{array}$ \\
\hline \multirow{3}{*}{$\begin{array}{c}\text { Pakchong } \\
-1\end{array}$} & $\begin{array}{c}40 \\
\text { days }\end{array}$ & $\begin{array}{c}167.8 \pm \\
1.56\end{array}$ & $66.8 \pm 2.97$ & $24.6 \pm 4.48$ & $17.78 \pm 0.70$ & $10.67 \pm 0.19$ & $\begin{array}{c}17.83 \pm \\
1.15\end{array}$ \\
\hline & $\begin{array}{c}50 \\
\text { days }\end{array}$ & $\begin{array}{c}204.2 \pm \\
3.54\end{array}$ & $81.2 \pm 4.31$ & $17.6 \pm 1.63$ & $15.61 \pm 0.37$ & $11.58 \pm 0.31$ & $\begin{array}{c}17.83 \pm \\
1.15 \\
\end{array}$ \\
\hline & $\begin{array}{l}60 \\
\text { days }\end{array}$ & $\begin{array}{c}263.0 \pm \\
8.23\end{array}$ & $80.4 \pm 6.91$ & $22.6 \pm 2.84$ & $15.15 \pm 0.55$ & $13.63 \pm 0.71$ & $\begin{array}{c}17.83 \pm \\
1.15\end{array}$ \\
\hline \multirow{2}{*}{ Cultivar } & $\mathrm{BN}-3$ & $\begin{array}{c}237.6 \pm \\
3.98 \\
\end{array}$ & $76.6 \pm 3.29$ & $19.07 \pm 1.6$ & $13.01 \pm 0.34$ & $12.89 \pm 0.27$ & $\begin{array}{c}17.34 \pm \\
0.42 \\
\end{array}$ \\
\hline & Pakchong-1 & $\begin{array}{c}211.67 \pm \\
3.98 \\
\end{array}$ & $76.13 \pm 3.29$ & $21.6 \pm 1.6$ & $16.18 \pm 0.34$ & $11.96 \pm 0.27$ & $\begin{array}{c}20.43 \pm \\
0.42 \\
\end{array}$ \\
\hline \multirow{3}{*}{ CI } & 40 days & $\begin{array}{c}175.2^{\mathrm{a}} \pm \\
4.88\end{array}$ & $74.1 \pm 4.03$ & $22.6 \pm 1.99$ & $15.35 \pm 0.41$ & $10.31^{\mathrm{a}} \pm 0.34$ & $\begin{array}{c}19.37 \pm \\
0.52\end{array}$ \\
\hline & 50 days & $\begin{array}{c}213.0^{\mathrm{b}} \pm \\
4.88\end{array}$ & $77.7 \pm 4.03$ & $20.0 \pm 1.99$ & $14.05 \pm 0.41$ & $11.69^{b} \pm 0.34$ & $\begin{array}{c}18.46 \pm \\
0.52 \\
\end{array}$ \\
\hline & 60 days & $\begin{array}{c}285.7^{c} \pm \\
4.88\end{array}$ & $77.3 \pm 4.03$ & $18.4 \pm 1.99$ & $14.38 \pm 0.41$ & $15.29^{c} \pm 0.34$ & $\begin{array}{c}18.83 \pm \\
0.52\end{array}$ \\
\hline \multirow{3}{*}{$\begin{array}{l}\text { Significan } \\
\text { ce level }\end{array}$} & Cultivar & $* *$ & NS & NS & $* *$ & $*$ & $* *$ \\
\hline & $\mathrm{CI}$ & $* *$ & NS & NS & NS & $* *$ & NS \\
\hline & $\begin{array}{c}\text { Cultivar } \times \\
\text { CI }\end{array}$ & $*$ & NS & NS & $*$ & $* *$ & NS \\
\hline
\end{tabular}

** $(p<0.01) ; *(p<0.05) ; N S$, Non Significant; BN-3, Bangladesh Livestock Research Institute developed Napier hybrid-3; CI, Cutting interval. $a, b$ and $c$ values within the same column with different superscripts differs significantly.

Besides, the number of tillers declined ( $P>0.05$ ) with the increasing cutting period. There was also a significant effect of cutting interval on the number of leaves per tiller $(P<0.01)$, with leaves increased progressively as the cutting period increased.

\section{DM production and LSR}

Cultivar had a significant effect on leaf DM production $(P<0.05)$; higher leaf $D M$ was produced from Pakchong-1, but no effect on stem DM yield, whereas the cutting period had a significant $(P<0.05)$ effect on leaf and stem DM yield (Table 2). Leaf and stem DM yield was increasing with the increasing harvest period. Although higher leaf DM was produced from
Pakchong-1, total DM did not differ significantly between cultivars. DM percentage of $\mathrm{BN}-3$ and Pakchong- 1 at 40,50 , and 60 days were 13.73, $15.91,24.60$ and 11.90, 14.68 and 15.05, respectively (data not shown in the table). This data suggest that at 60 days harvest period, Napier was harder than Pakchong-1. Pakchong-1 produced significantly higher LSR $(P<0.05)$ as compared to $\mathrm{BN}-3$, and with the increasing cutting period, LSR decreased significantly $(P<$ 0.05). 
Table 2: Effects of cultivar and cutting period on leaf and stem DM and CP production and LSR of BN-3 and Pakchong- 1 cultivars (mean \pm SE)

\begin{tabular}{|c|c|c|c|c|c|c|}
\hline \multirow[t]{2}{*}{ Treatments } & & & \multicolumn{4}{|c|}{ Parameters } \\
\hline & & & $\begin{array}{l}\text { Leaf DMY } \\
\text { (kg/plant) }\end{array}$ & $\begin{array}{l}\text { Stem DMY } \\
\text { (kg/plant) }\end{array}$ & $\begin{array}{l}\text { DM yield } \\
\text { (kg/plant) }\end{array}$ & LSR \\
\hline \multirow{3}{*}{$\mathrm{BN}-3$} & \multirow{3}{*}{$\vec{U}$} & 40 days & $0.15 \pm 0.03$ & $0.11 \pm 0.03$ & $0.26 \pm 0.06$ & $0.62 \pm 0.03$ \\
\hline & & 50 days & $0.18 \pm 0.02$ & $0.21 \pm 0.03$ & $0.40 \pm 0.04$ & $0.53 \pm 0.03$ \\
\hline & & 60 days & $0.18 \pm 0.02$ & $0.34 \pm 0.03$ & $0.52 \pm 0.04$ & $0.46 \pm 0.02$ \\
\hline \multirow{3}{*}{ Pakchong-1 } & \multirow{3}{*}{ U } & 40 days & $0.15 \pm 0.01$ & $0.09 \pm 0.00$ & $0.24 \pm 0.01$ & $0.75 \pm 0.03$ \\
\hline & & 50 days & $0.18 \pm 0.01$ & $0.16 \pm 0.01$ & $0.34 \pm 0.02$ & $0.57 \pm 0.02$ \\
\hline & & 60 days & $0.36 \pm 0.05$ & $0.32 \pm 0.05$ & $0.68 \pm 0.10$ & $0.51 \pm 0.02$ \\
\hline \multirow{2}{*}{ Cultivar } & \multicolumn{2}{|c|}{$\mathrm{BN}-3$} & $0.17 \pm 0.02$ & $0.22 \pm 0.02$ & $0.39 \pm 0.03$ & $0.54 \pm 0.02$ \\
\hline & \multicolumn{2}{|c|}{ Pakchong-1 } & $0.23 \pm 0.02$ & $0.19 \pm 0.02$ & $0.42 \pm 0.03$ & $0.61 \pm 0.02$ \\
\hline \multirow{3}{*}{ CI } & \multicolumn{2}{|c|}{40 days } & $0.15^{a} \pm 0.02$ & $0.10^{\mathrm{a}} \pm 0.02$ & $0.25^{\mathrm{a}} \pm 0.04$ & $0.69^{c} \pm 0.02$ \\
\hline & \multicolumn{2}{|c|}{50 days } & $0.18^{\mathrm{a}} \pm 0.02$ & $0.19^{b} \pm 0.02$ & $0.37^{b} \pm 0.04$ & $0.55^{b} \pm 0.02$ \\
\hline & \multicolumn{2}{|c|}{60 days } & $0.27^{b} \pm 0.02$ & $0.33^{c} \pm 0.02$ & $0.60^{\complement} \pm 0.04$ & $0.49^{a} \pm 0.02$ \\
\hline \multirow{3}{*}{$\begin{array}{l}\text { Significance } \\
\text { level }\end{array}$} & \multicolumn{2}{|c|}{ Cultivar } & $*$ & NS & NS & $*$ \\
\hline & \multicolumn{2}{|c|}{$\mathrm{CI}$} & $* *$ & $* *$ & $* *$ & $* *$ \\
\hline & \multicolumn{2}{|c|}{ Cultivar $\times$ CI } & $*$ & NS & NS & NS \\
\hline
\end{tabular}

** $(p<0.01) ; *(p<0.05) ; N S$, Non Significant; BN-3, Bangladesh Livestock Research Institute developed Napier hybrid-3; CI, Cutting interval; DM, dry matter; DMY, dry matter yield. $a, b$ and $c$ values within the same column with different superscripts differs significantly.

Table 3: Effect of cultivar and cutting period on CP content in leaf and stem for BN-3 and Pakchong-1

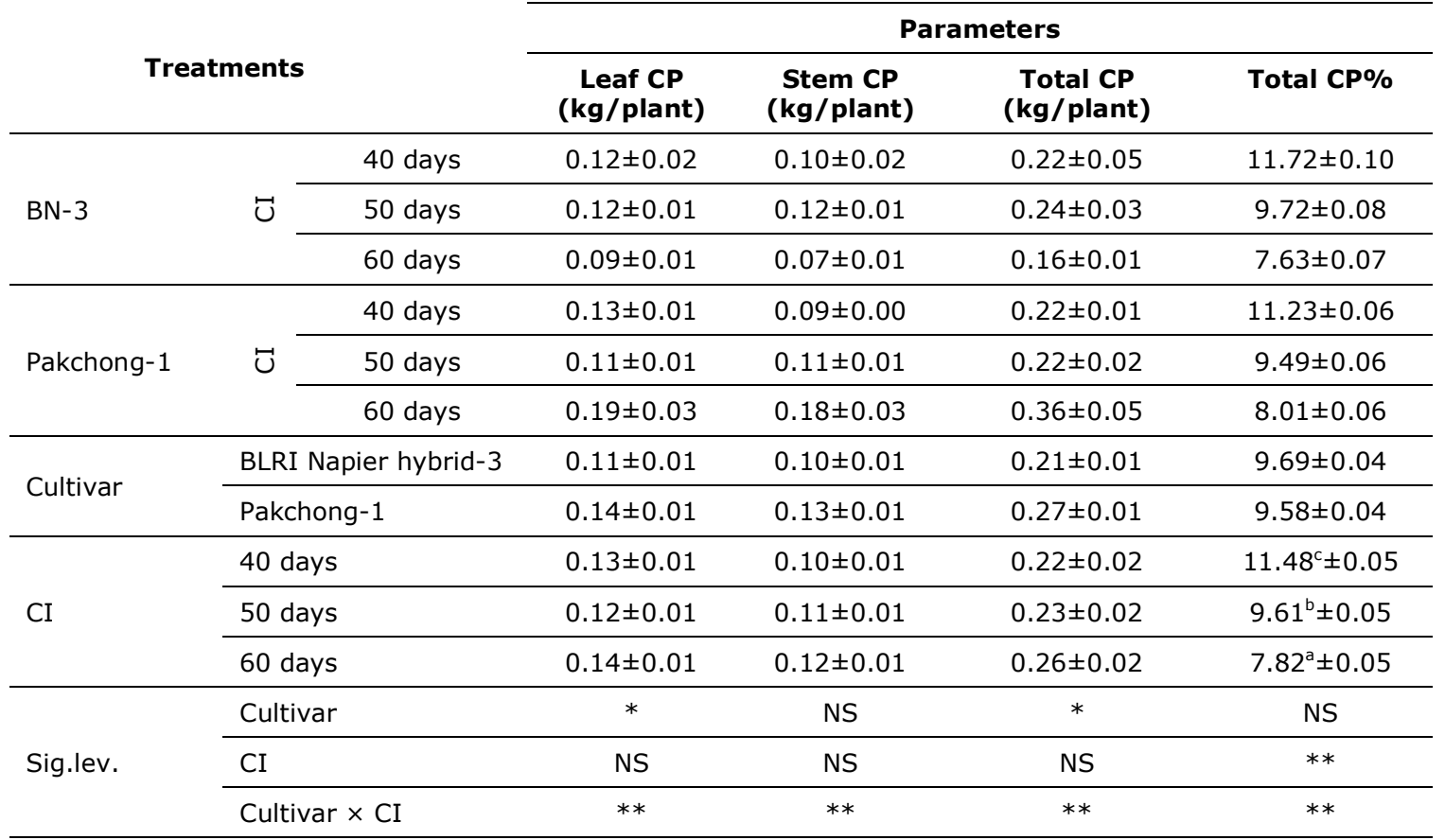

** $(p<0.01) ; *(p<0.05) ; N S$, Non Significant; BN-3, Bangladesh Livestock Research Institute developed Napier hybrid-3; $C P$, crude protein; $C I$, Cutting interval. $a, b$ and $c$ values within the same column with different superscripts differs significantly 


\section{CP content in different botanical fraction of plant}

The cultivar had a significant effect on leaf $\mathrm{CP}$ content, and Pakchong-1 produced higher leaf $\mathrm{CP}$ thanBN-3(Table 3). Leaf CP content of Napier and Pakchong-1 at 40, 50, 60 days cutting interval were $0.12,0.12,0.09$ and $0.13,0.11,0.19 \mathrm{~kg}$ per plant, respectively. Interaction between cultivar and cutting period also differ significantly $(P<0.01)$. Data reveals that with increasing cutting period, the leaf $\mathrm{CP}$ concentration of $\mathrm{BN}-3$ decreasing but higher leaf $\mathrm{CP}$ concentration of Pakchong-1 observed at 60 days cutting interval. Similarly, stem CP concentration also decreases with the increasing cutting interval for Napier, but Pakchong-1 higher stem CP concentration is observed at 60 days cutting interval. Pakchong-1 produced a significantly $(P<0.05)$ higher amount of $\mathrm{CP}$ than that produced from $\mathrm{BN}-3$, although the cutting period had no significant effect on total CP yield irrespective of the cultivar. Though \% CP in the whole plant did not differ between cultivars, \% CP significantly $(P<$ 0.05) decreased with the increasing cutting period.

\section{Correlations among growth parameters}

Correlations among different growth parameters are presented in Table 4. While plant height, leaf and stem DM, and leaves per plant positively and strongly correlated $(P<0.01)$ with each other. On the other hand, LSR was negatively and strongly correlated with plant height $(P<0.01)$, leaves per plant $(P<0.05)$, leaf DM $(P<0.05)$, and stem DM $(P<0.01)$, but had a positive correlation $(P<0.05)$ with no. of tiller and tiller diameter. This complementary information supports our above findings.

\section{Discussion}

This study has provided useful information on the possible yields, growth, and nutritional quality of Napier hybrid developed by Bangladesh Livestock Research Institute and Pakchong-1, imported from Thailand at different cutting periods in Bangladesh's flatlands. The variation in different parameters among these two varieties suggests room for selection if the aim is to establish breeding programs to improve yields in Bangladesh's environmental condition.

The significantly bigger tillers and numbers, higher leafiness, and overall CP production in Pakchong-1 highlight this cultivar's vigorous growth and yield and its adaptation to the wet subtropical conditions in Bangladesh's flatlands. Pakchong-1 was also little beneficial than BN-3 regarding LSR and its biomass yield at about 60 days cutting period. Variable characteristics of stem and leaves of the cultivars create significant variation $(p<0.05)$ of LSR between them. Better LSR as obtained from Pakchong-1 was due to higher leaf and leaf dry matter yield of Pakchong1 than BN-3. However, the LSR dropped abruptly according to the rise of the harvest period. Reduction in LSR with extended cutting intervals is a function of the longer periods of physical development with declined defoliation frequency stimulating stem growth at leaf production expense (Butt et al., 1993; Wangchuk et al., 2015).

Table 4: Correlations between growth and production parameters

\begin{tabular}{lccccccc}
\hline Parameters & $\begin{array}{c}\text { Basal } \\
\text { circumf } \\
\text { erence }\end{array}$ & $\begin{array}{c}\text { Plant } \\
\text { height }\end{array}$ & $\begin{array}{c}\text { No. of } \\
\text { tillers }\end{array}$ & $\begin{array}{c}\text { Tiller } \\
\text { diameter }\end{array}$ & $\begin{array}{c}\text { Leaves } \\
\text { /plant }\end{array}$ & $\begin{array}{c}\text { Leaf } \\
\text { dry } \\
\text { matter }\end{array}$ & $\begin{array}{c}\text { Stem } \\
\text { dry } \\
\text { matter }\end{array}$ \\
\hline Plant height (cm) & 0.11 & & & & & & \\
No. of tillers (no.) & -0.14 & -0.25 & & & & & \\
Tiller diameter (mm) & -0.04 & -0.28 & 0.02 & & & & \\
Leaves/plant (no.) & -0.04 & $0.46^{* *}$ & $0.50^{* *}$ & -0.26 & & & \\
Leaf DM (kg/plant) & 0.25 & $0.45^{* *}$ & $0.38^{*}$ & 0.11 & 0.69 & \\
Stem DM (kg/plant) & 0.14 & $0.88^{* *}$ & 0.03 & -0.19 & $0.68 * *$ & $0.72 * *$ & \\
& -0.23 & $-0.78^{* *}$ & $0.33^{*}$ & $0.34 *$ & $-0.36^{*}$ & $-0.36^{*}$ & $-0.75^{* *}$ \\
\hline
\end{tabular}


BN-3 appeared lower to Pakchong-1 in most morphological traits except for plant height. It was superior to Pakchong- 1 in terms of plant height with performed better at about 50 days cutting period. Although plant height and tillering in grasses are controlled genetically, they can be modified mostly by selection with the little extent to environmental factors (Assuero and Tognetti, 2010). However, the reduction of tiller number with increasing cutting intervals for both cultivars conforms to Onyeonagu and Asiegbu (2012) reports, where the tillering is enhanced under frequent cutting. Increased tillering is probably a viable characteristic to abide by frequent defoliation by re-establishing lost photosynthetic area and maintaining the basal area, while low tiller production under long cutting intervals has been linked to higher mortality of tillers under reduced cutting frequency (Clavero, 1997). Almost every cutting regime Pakchong-1 produced the highest number of tillers, which exhibits the abundant tillering capacity of this cultivar (Premaratne and Premalal, 2006). A significantly higher tiller diameter was found in this cultivar than BN-3. Tiller production is a vital feature in the resistance of grasslands to deterioration by aging (Lafarge and Loiseau, 2002), which indicates sustainable productivity (Mukhtar, 2006) with associated with better persistence after periods of adverse environmental conditions (Assuero and Tognetti, 2010).

Despite the higher leaf DM production of Pakchong-1, both cultivars were similar on stem and total DM yield, whereas the cutting period had a significant $(P<0.05)$ effect on leaf and stem DM yield. The quality of pasture and animals' performance is associated with the amount and quality of leaf in the diet (Davison et al., 1981; Tudsri et al., 2002). On the other hand, CP concentration in the whole plant did not differ between cultivars, but it was significantly declined with the increasing cutting period. Similar findings were revealed by Tessema et al. (2010). DM yields were seriously reduced of all cultivars in 40 days cutting interval, while protein concentration was very high, which would scarcely compensate for the seriously reduced fodder production. With increasing cutting period, the leaf and stem $\mathrm{CP}$ concentration of $\mathrm{BN}-3$ decreasing but a higher $\mathrm{CP}$ concentration of Pakchong-1 observed at 60 days cutting period for leaf and stem. However, the cutting period had no significant effect on total CP yield irrespective of the cultivar. Khaled et al. (2005) and Peiretti et al. (2015) stated similar results of the decline in $\mathrm{CP}$ with advancing phonological stages. Therefore, an intermediate cutting interval of 60 days of Pakchong-1 appears optimal for Bangladesh's flatlands. However, supplementary studies with animal performance trials with considering detail cost-effective analysis are recommended for more tangible outcomes.

\section{Conclusion}

Both the grass cultivars performed well in the experimental site, but they varied in terms of growth characteristics, forage yield, and quality. $\mathrm{BN}-3$ was superior to Pakchong-1 only in terms of plant height, but Pakchong-1 had bigger tillers with numbers, higher leafiness, and overall CP production. From the forage standpoint, Pakchong- 1 has non-significant advantages over $\mathrm{BN}-3$ because of its LSR and higher amount of $\mathrm{CP}$ production.BN-3 performed better at about 50 days cutting period, but Pakchong-1 performed better at about 60 days cutting period. However, further research with animal performance trials considering detail economic analysis is recommended for more concrete results.

\section{Acknowledgements}

The authors gratefully acknowledge the funding and research support of Bangladesh Livestock Research Institute, Savar, Dhaka-1341, Bangladesh, for conducting the experiment.

\section{Conflict of interest}

The authors declare that there is no conflict of interest that could be perceived as prejudicing the impartiality of the research reported.

\section{References}

Assuero SG and JA Tognetti (2010). Tillering regulation by endogenous and environmental factors and its agricultural management. The American Journal of Plant Science and Biotechnology 4:35-48.

Butt NM, B Gary, MG Donart, RD Southward and M Noror (1993). Effects of defoliation on plant growth of napier grass. Tropical Science 33:111-120.

Clavero LT (1997). Tiller dynamics of dwarf elephant grass (Pennisetum purpureum cv. Mott) under defoliation. Proceedings of the XVIII International Grassland Congress, Winnipeg and Saskatoon, Canada.P. 31-32.

Davison TM, RT Cowan and PK O'Rourke (1981). Management practices for tropical grasses and their effects on pasture and milk production. Australian Journal of Experimental Agriculture and Animal Husbandry 21:196-202. 
Dunièrea L, J Sindoub, F Chaucheyras-Durand, I Chevallier and D Thévenot-Sergentet (2013). Silage processing and strategies to prevent persistence of undesirable microorganisms. Animal Feed Science and Technology 182:115.

Hasan M, MA Islam, MA Hasan, MJ Alam and MH Peas (2019). Ground water vulnerability assessment in Savarupazila of Dhaka district, Bangladesh - A GIS-based DRASTIC modeling. Groundwater for Sustainable Development 9:100220.

Huque KS, MK Bashar, NR Sarker, N Sultana, BK Roy, S Amhed and HPS Makkar (2017). Annual biomass production, chemical composition and in-sacco degradability of different cultivars of Moringa oleifera. International Journal of Environment, Agriculture and Biotechnology 2:864-873.

Khaled RAH, M Duru and P Cruz (2005). Are leaf traits suitable for assessing the feeding value of native grass species? Proceedings of the $X X$ International Grassland Congress, Dublin, Netherlands.

Kiyothong K (2014). Anonymous. Miracle grass seen to boost local dairy production.www.pinoyfeeds.com/Supernapier.html

Lafarge M and P Loiseau (2002). Tiller density and stand struc-ture of tall fescue swards differing in age and nitrogen level. European Journal of Agronomy17:209-219.

LGED 2014. Annual Report. Local Government Engineering Department, Peoples' Republic of Bangladesh.

Mukhtar M (2006). Dry matter productivity of the dwarf and normal elephant grasses as affected by the planting density and cutting frequency. Indonesian Journal of Animal and Veterinary Sciences 11:198-205.

Onyeonagu CC and JE Asiegbu (2012). Influence of cutting frequency and fertilizer- $\mathrm{N}$ application on tiller production and herbage yield distribution over time in a guinea grass
(Panicum maximum) sown pasture. African Journal of Biotechnology 11:7170-7185.

Pandey KC and AK Roy (2011). Forage Crops Varieties. Indian Grassland and Fodder Research Institute (IGFRI), Jhansi, Uttar Pradesh, India.

Peiretti PG, F Gai and S Tassone (2015). Nutritional value and fatty acid profile of Niger (Guizotiaa byssinica) plant during its growth cycle. Livestock Research for Rural Development 27:18-25.

Premaratne S and GGC Premalal (2006). Hybrid Napier (Pennisetumperpureum $\quad X$ Pennisetumamericarnum) var. CO-3: A resourceful fodder grass for dairy development in Sri Lanka. The Journal of Agricultural Sciences 2:22-33.

Sarker NR, D Yeasmin, F Tabassum, MR Amin and MA Habib (2019). Comparative study on biomass yield, morphology, silage quality of hybrid napier and pakchong and their utilization in bull calves. Journal of Agricultural Science and Technology 9:166-176.

TessemaZK, J Mihret and M Solomon (2010). Effect of defo-liation frequency and cutting height on growth, dry-matter yield and nutritive value of Napier grass (Pennisetum purpureum (L.) Schumach). Grass and Forage Science 65:421430.

Tudsri S, Y Ishii, H Numaguchi and S Prasanpanich (2002). The effect of cutting interval on the growth of Leucaenaleucocephala and three associated grasses in Thailand. Tropical Grasslands 36:90-96.

Van Soest PJ, JB Robertson and BA Lewis (1991) Methods for dietary fiber, neutral detergent fiber, and non-starch polysaccharides in relation to animal nutrition. Journal of Dairy Science 74:3583-3597.

Wangchuk K, K Rai, H Nirola, A Thukten, C Dendup and D Mongar (2015). Forage growth, yield and quality responses of napier hybrid grass cultivars to three cutting intervals in the Himalayan foothills. Tropical Grasslands 3:142150. 